\title{
Temperature-parasitism synergy alters intertidal soft-bottom community structure
}

\author{
Martin H. Larsen, Kim N. Mouritsen * \\ Department of Bioscience, Aquatic Biology, University of Aarhus, Ole Worms Allé 1, DK-8000 Aarhus C, Denmark
}

\section{A R T I C L E I N F O}

\section{Article history:}

Received 30 January 2014

Received in revised form 13 June 2014

Accepted 18 June 2014

Available online $\mathrm{xxxx}$

\section{Keywords:}

Corophium volutator

Ecosystem functioning

Macrofauna

Meiofauna

Microphytobenthos

Parasites

\begin{abstract}
A B S T R A C T
The abundant amphipod Corophium volutator is an ecosystem engineer in soft-bottom intertidal communities due to its grazing and bioturbation activity. However, the amphipod commonly serves as second intermediate host for detrimental microphallid trematodes. This host-parasite association is potentially very sensitive to climate change as the transmission rate of larval trematodes (cercariae) from first intermediate hosts (mud snails) to amphipods, and hence infection intensity-dependent amphipod mortality, generally accelerates with increasing temperature. Given the ecosystem engineering role of $C$. volutator, we hypothesized that elevated temperature, indirectly through increased parasite-induced amphipod mortality, significantly affects the structure of the surrounding benthic community. To test this, we performed a three-month outdoor mesocosm experiment exposing a natural soft-bottom community of benthic plants and animals to four different treatments: relatively low mean water temperature $\left(18{ }^{\circ} \mathrm{C}\right)$ with low $(<4 \%)$ and high $(\mathrm{c} .31 \%)$ trematode prevalence in the snail population, and relatively high mean water temperature $\left(22^{\circ} \mathrm{C}\right)$ with low and high trematode prevalence. Both temperature and snail parasitism had a significant impact on amphipod abundance and resulted in their almost complete eradication at the warm temperature with high parasitism. Aside from the amphipod hosts, increased temperature affected the abundance of eight faunal species out of 22 in total (36\%), whereas increased level of parasitism or the parasite-temperature interaction influenced the density of three species (14\%). The treatment-determined Corophium abundance played an isolated role for several species, particularly the polychaetes Hediste diversicolor (positive) and Polydora ligni (negative). Regarding primary producers, the overall frequency distribution of 21 species of benthic diatoms differed between all four treatments. Species-specific effects were few and weak, however, and microalgal abundance (chlorophyll- $a$ ) was statistically unaffected by treatments, together suggesting a rather resilient plant community towards the experimental perturbations. At the community level, the non-host macrofaunal diversity decreased with temperature in the low parasitism treatments whereas it increased with temperature in the high parasitism treatments. This suggests that sufficiently high levels of parasitism may turn a negative effect of elevated temperature on macrofaunal biodiversity into a positive effect. Hence, our experiment demonstrates that the synergy between parasitism and a relevant temperature increase, e.g. in lieu of climate oscillations or global warming, may have broad ecological consequences for the organization and function of soft-bottom communities, in part through elevated parasite-induced mortality of a central community member.
\end{abstract}

(c) 2014 Elsevier B.V. All rights reserved.

\section{Introduction}

Parasitism has been acknowledged as a major factor that can regulate the abundance of host populations (Scott, 1987), alter the structure of plant and animal communities (Minchella and Scott, 1991; Mouritsen and Poulin, 2002a; Poulin, 1999; Wood et al., 2007), and affect the functioning of ecosystems (Sousa, 1991; Thomas et al., 2005). At the same time, there has been a growing awareness that climate change

\footnotetext{
* Corresponding author. Tel.: +4587156113.

E-mail address: kim.mouritsen@biology.au.dk (K.N. Mouritsen).
}

may increase the frequency of parasitic diseases in both terrestrial and aquatic environments (Harvell et al., 1999, 2002; Marcogliese, 2001). In particular, it has been emphasized that the transmission of marine trematodes is sensitive to even small temperature changes (e.g. Mouritsen, 2002; Mouritsen and Jensen, 1997; Poulin, 2006; Studer et al., 2010; Thieltges and Rick, 2006). Given that parasitism is capable of organizing natural ecosystems and that trematodes appear particularly sensitive to temperature, it becomes imperative to elucidate the potential responses of host-parasite systems to climate fluctuations, including climate warming. Accordingly, recent reviews have focused their attention on understanding the consequences of such temperature-parasite synergism on entire coastal ecosystems (Marcogliese, 2001, 2008; Mouritsen and Poulin, 2002b; Poulin and 
Mouritsen, 2006). There remains, however, great uncertainty about how and to what extent environmental factors affect marine hostparasite systems, and in turn the ramifications to the surrounding community of plants and animals. Specifically, to our knowledge, no studies have examined the potential effects of increasing temperature on coastal benthic community structure through elevated parasiteinduced mortality rates of a single ecologically important community member.

The amphipod Corophium volutator is often a dominant macrofaunal organism in intertidal soft-sediment environments on both sides of the North Atlantic, occasionally reaching densities of 100000 individuals $\mathrm{m}^{-2}$. Corophium volutator is an important prey item for demersal fishes, benthic invertebrates and migratory shorebirds (Daborn et al., 1993; Mouritsen, 1994; Pihl, 1985). It belongs to the infauna and lives in U-shaped burrows in the upper layer of the sediment. Due to the amphipods burrowing and grazing activities they may alter sediment characteristics of mud-flats and influence benthic community structure (Daborn et al., 1993; Gerdol and Hughes, 1994a; Mouritsen et al., 1998). Hence, amphipods may be regarded as ecosystem engineers in softbottom intertidal communities (Jones et al., 1997).

Corophium volutator acts as second intermediate host for a variety of microphallid trematodes. The most common microphallid species along eastern Atlantic coasts belong to the genera Maritrema and Microphallus (Deblock, 1980; Jensen and Mouritsen, 1992). The complex life cycle of these parasites also includes the mud snail Hydrobia ulvae as first intermediate host, and shorebirds as definitive hosts. After the parasite eggs are ingested by the mud snail, larval trematodes are continuously produced asexually within the snail's gonads and released as freeswimming cercariae that seek out and penetrate the cuticle of C. volutator. The cercariae encyst as metacercariae within the body cavity of the amphipods and await ingestion by an appropriate shorebird host in order to complete their life cycle. This host-parasite system is very sensitive to environmental factors, particularly temperature. Usually, increasing temperature accelerates the development of larval trematodes within the snails, as well as triggering their release (Meissner and Bick, 1999a; Mouritsen, 2002; Mouritsen and Jensen, 1997). This temperature-mediated increase in cercarial output in turn increases severe infection intensity of amphipods, as the transmission efficiency (proportion of cercariae successfully reaching the second intermediate host) remains roughly constant with increasing temperature within naturally occurring ranges (Mouritsen and Jensen, 1997; Studer et al., 2010). Consequently, the infection intensity-dependent parasite-induced amphipod mortality is likely to increase as temperature rises (Jensen and Mouritsen, 1992; Larsen et al., 2011; Meissner and Bick, 1999a,b; Mouritsen and Jensen, 1997; Mouritsen et al., 2005). Indeed, parasite-induced mass mortality in a local amphipod population has been observed in the Danish Wadden Sea during a period of unusual high temperatures (Jensen and Mouritsen, 1992). The disappearance of the tube-building amphipod led to increased sediment erosion and significant changes of the sediment characteristics (see Mouritsen et al., 1998). However, the direct as well as indirect consequences of such temperature-parasitism synergy on surrounding benthic flora and fauna have not yet been thoroughly quantified (Larsen et al., 2011; Mouritsen et al., 1998).

Here, we use the above mentioned host-parasite system to elucidate the effect of temperature-parasitism synergy on intertidal community structure. We hypothesize that temperature-dependent parasiteinduced amphipod mortality leads to significant structural changes of the surrounding benthic community. To test this, we performed a threemonth outdoor mesocosm experiment designed to unravel (1) the combined effect of temperature and microphallid parasitism on the density of $C$. volutator, (2) the ramifications on the community of benthic microalgae, meiofauna and macrofauna that may follow, and (3) the community consequences of altered temperature and parasitism stemming from other processes than parasite-mediated reduction in amphipod density.

\section{Materials and methods}

\subsection{Experimental design}

The outdoor mesocosm experiment was conducted at Rønbjerg Marine Biological Station, Limfjorden, Denmark, from 6 July to 21 September 2009. The experimental mesocosm unit was a circular PVC container, $16.5 \mathrm{~cm}$ in height and an inner diameter of $15 \mathrm{~cm}$ resulting in a $177 \mathrm{~cm}^{2}$ bottom surface area. Two $\mathrm{cm}$ below the top of the container, 4 holes (each $0.8 \mathrm{~cm}^{2}$ ) covered with a $500 \mu \mathrm{m}$ polyethylene mesh were used as a drain, which hence allowed for a certain level of emigration of smaller resuspended organisms. To help maintaining the desired water temperature (see below) the containers were insulated on the outside with flexible polyurethane foam $(10 \mathrm{~mm})$.

Four different treatments were assigned to 28 such containers (i.e. $n=7$ per treatment), fully randomized in a $4 \times 7$ block design: (1) low water temperature and low parasitism, (2) low water temperature and high parasitism, (3) high water temperature and low parasitism, and (4) high water temperature and high parasitism (high and low parasitism refer to prevalence of infection in the experimental snail population; see Section 3.2.2 for realized infection levels across treatments). The low water temperature treatment was designed to reflect the present mean summer temperature of coastal areas in Denmark $\left(\mathrm{c} .18^{\circ} \mathrm{C}\right.$; data available at http://www.seatemperature.org/), whereas the high water temperature treatment aimed at a temperature $4{ }^{\circ} \mathrm{C}$ above the present level $\left(22^{\circ} \mathrm{C}\right)$. The latter corresponds to the expected rise in ambient air temperature in Denmark within this century (Christensen et al., 1998, 2001), bound to also affect near-coastal water temperature.

Each container was supplied with $6.5 \mathrm{~cm}$ substrate (see Section 2.2) and its own seawater supply (25-30\%) at a flow rate of $0.16 \mathrm{~L} \mathrm{~min}^{-1}$. The latter corresponds to a retention time of approximately 9 min of the resulting water column of $8.0 \mathrm{~cm}$ (water volume: $1.4 \mathrm{~L}$ ). This relatively high flow rate served to achieve the required temperature and to ensure well-oxygenated mesocosms. In order to avoid invasion of non-experimental organisms the applied seawater was filtered through a sand filter followed by a $25 \mu \mathrm{m}$ pleated polyester filter and a $5 \mu \mathrm{m}$ string wound filter. The filtered water was then directed through coiled tubes submerged in either cooled or heated water baths to achieve outflow temperatures of 18 and $22{ }^{\circ} \mathrm{C}$, respectively. The cooled and heated water was directed into two separate insulated PVC tubes $(\varnothing=5 \mathrm{~cm}$, length $=230 \mathrm{~cm}$ ) functioning as water reservoirs. This was done to obtain a constant water flow to each experimental mesocosm unit in addition to equal water temperature among containers within each of the two temperature treatments. Finally, short silicon tubes connected to these PVC tubes were used to supply each container with desired seawater quality. During experimentation, the water temperature was measured every $30 \mathrm{~min}$ by temperature loggers submerged in two haphazardly chosen experimental mesocosm units from each temperature treatment. The resulting water temperature in the low and high temperature treatments was $17.9 \pm 0.01$ and $22.0 \pm 0.01{ }^{\circ} \mathrm{C}$ (mean \pm SE), respectively (Fig. 1). The experimental set-up allowed to a certain extent for the influence of fluctuating ambient temperatures and influx of sun radiation, thereby reflecting greater realism. Based on daily measurements at 15:00 PM and 03:00 AM, the variance in water temperature was statistical similar between the high and low temperature treatments over the course of the experiment (Levene's test, $F_{1,304}=2.795, p=0.096$ ). On July 27 (experimental day 22 ), the water temperature dropped to $17.8{ }^{\circ} \mathrm{C}$ during a two hours period in the high temperature treatment due to technical problems with the thermostat. However, this short-termed temperature drop is judged to have no significant bearing on obtained results.

\subsection{Sediment, microflora and meiofauna}

The sediment used in the experiment contained naturally occurring microflora and meiofauna community of initially unknown composition. 


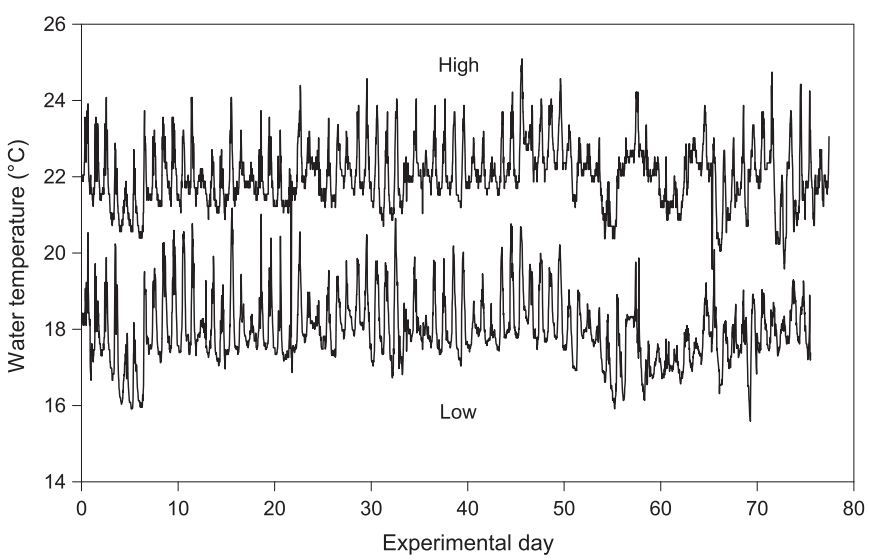

Fig. 1. Experimental water temperature in the two temperature treatments during the outdoor mesocosm experiment. Each 30 min value is the average recording of two temperature loggers placed in two haphazardly chosen experimental units from each temperature treatment.

Sediment was collected on an intertidal mudflat (200-300 m from mean high water level) in the Danish Wadden Sea near Ribe Kammersluse $\left(55^{\circ} 21^{\prime} \mathrm{N}, 8^{\circ} 39^{\prime} \mathrm{E}\right)$ using a modified PVC ring $(\varnothing=15 \mathrm{~cm}$, height $=$ $10 \mathrm{~cm}$ ). The ring was pushed $6.5 \mathrm{~cm}$ into the substrata after which the upper $2.5 \mathrm{~cm}$ layer (where the majority of microalgae and meiofauna reside) was removed with a spoon and transferred to a container (surface sediment). The remaining $4 \mathrm{~cm}$ of the sediment core was then stored in a separate container (bottom sediment). This protocol was repeated until a sufficient amount of surface and bottom sediment was sampled for the experiment.

In the laboratory, the two sediment fractions were sieved separately through a $250 \mu \mathrm{m}$ screen into large bowls to remove macrofaunal organisms. Although this protocol also retained the largest meiofaunal organisms, it was necessary in order to remove juvenile macrofauna, particularly amphipods, from the substrata. The sediment passing through the $250 \mu \mathrm{m}$ mesh was gently mixed and placed in trays (198 $\mathrm{x}$ $58 \times 5 \mathrm{~cm}$; length $\mathrm{x}$ width $\mathrm{x}$ height) with slowly running seawater ensuring that the naturally occurring organisms, especially meiofauna and benthic microalgae, were not flushed from the sediment. The surface sediment was established in a layer of $2.5 \mathrm{~cm}$ in a single tray, whereas the bottom sediment was distributed in four trays in a layer of c. 3-5 mm. The latter was done to avoid anoxic conditions to develop in this partly reduced sediment prior to the experiment. During the sifting process 2.7 and $1.1 \mathrm{~L}$ of sediment particles were retained on the $250 \mu \mathrm{m}$ mesh from the bottom and surface sediment, respectively. Hence, in order to restore particle composition and texture of the original sediment, rinsed beach sand (i.e. free of marine organisms) between $250-500 \mu \mathrm{m}$ in particle diameter was used to replace the lost sediment.

\subsection{Experimental macrofaunal organisms}

First intermediate snail hosts, $H$. ulvae, served as the source of microphallid parasites in the experiment. Specimens of $H$. ulvae were collected haphazardly according to in situ size distribution (range: 3.7-5.7 $\mathrm{mm}$ in shell height) during spring 2009 at localities known to support trematode-infected snails. Microphallid-infected mud snails were sampled in the Danish Wadden Sea between Skallingen $\left(55^{\circ} 31^{\prime} \mathrm{N}\right.$, $8^{\circ} 16^{\prime} \mathrm{E}$ ) and Emmerlev ( $\left.54^{\circ} 59^{\prime} \mathrm{N}, 8^{\circ} 39^{\prime} \mathrm{E}\right)$, while uninfected snails were collected from a lagoon situated in Limfjorden $\left(56^{\circ} 56^{\prime} \mathrm{N}, 9^{\circ} 12^{\prime} \mathrm{E}\right)$. The prevalence by microphallid-infection in this lagoon is usually low $(<5 \%)$, whereas c. $25 \%$ of the sampled snails from the Wadden Sea was infected by microphallid trematodes.

Snails were placed individually in small Petri dishes $(10 \mathrm{~mL} ; \varnothing=$ $35 \mathrm{~mm}$ ) supplied with seawater at $25{ }^{\circ} \mathrm{C}$ under artificial light for at least 6 hours to verify their infection status (i.e. likely uninfected or infected, identity of infection). Under these conditions, snails harboring mature trematode-infections start shedding trematode larvae (cercariae) within a few hours that can be readily seen under a stereomicroscope. Shed cercariae were then identified to at least genus level according to Deblock (1980) using a light microscope. Mud snails infected by the microphallid trematodes, Maritrema spp. and Microphallus spp., as well as snails scored to be uninfected were separated until commencement of the experiment. Note that the group of snails scored to be uninfected did contain some false negatives (see Section 3.2.2.). The snails were kept in aquaria in the laboratory at $15{ }^{\circ} \mathrm{C}$ and fed with sediment rich in diatoms and epiphytic algae growing on green macroalgae Ulva lactuca and Enteromorpha sp. To promote algae growth, the aquaria were positioned under growth lamps with 12-hour light-dark cycle. The seawater (25-28\%) and sediment were renewed every third week.

Amphipods, C. volutator, acting as second intermediate host for microphallid trematodes, were collected at the upper intertidal zone near Ribe Kammersluse a few days before the start of the experiment. To obtain similar-sized amphipods across treatments, only animals passing through a $2.0 \mathrm{~mm}$ mesh but retained by a $500 \mu \mathrm{m}$ mesh were selected for the experiment. A subsample of amphipods $(n=250)$ was preserved in $80 \%$ ethanol and subsequently measured from rostrum to telson under a dissection microscope to determine initial mean length. After measurement, the amphipods were dissected and examined for pre-experimental infection level (metacercariae). The average body length of this source population of amphipods was $5.2 \pm 0.03$ (SE) $\mathrm{mm}$ (range: 3.2-6.2 mm). The pre-experimental average microphallid infection intensity was 0.6 metacercariae per individual (range: $0-5$ ). Hence, the population of amphipods used in the experiment was largely unaffected by microphallid trematodes (see e.g. Mouritsen and Jensen, 1997). The sex-ratio of the amphipods was not statistically different from even (Goodness-of-fit test, $\chi^{2}{ }_{1}=$ $0.351, p=0.554$ ).

Other planned experimental macrofaunal organisms were restricted to the numerically dominant intertidal species obtained in core samples (each $50 \mathrm{~cm}^{2}$ ) haphazardly collected near Ribe Kammersluse: the polychaete Hediste diversicolor, the bivalve Macoma balthica and the oligochaete Tubificoides benedeni. The initial length of $H$. diversicolor (preserved in $80 \%$ ethanol) ranged between $14-26 \mathrm{~mm}(\mathrm{n}=45)$. The mean initial shell height (maximum height) of $M$. balthica was $4.8 \pm$ 0.08 (SE) $\mathrm{mm}(\mathrm{n}=49)$, and the pre-experimental mean length of T. benedeni (preserved in $80 \%$ ethanol) was $8.4 \pm 0.23(\mathrm{SE}) \mathrm{mm}(\mathrm{n}=45)$.

\subsection{Establishment of experiment}

\subsubsection{Addition of sediment}

The bottom sediment was transferred from the storage trays into a large bowl. Following homogenization, $0.7 \mathrm{~L}$ of sediment was added to each experimental mesocosm unit, equivalent to a sediment depth of $4 \mathrm{~cm}$. To add surface sediment, 28 modified PVC rings $(\varnothing=15 \mathrm{~cm})$ were pushed into the established sediment in the storage tray. The sediment inside each ring was then removed with a spoon and added to the container, resulting in an additional sediment layer of $2.5 \mathrm{~cm}$. To achieve a homogeneous surface sediment layer in the containers, the sediment was added by sieving it through a $2 \mathrm{~mm}$ mesh in the water column established above the bottom sediment. After sediment addition, containers were placed at $18{ }^{\circ} \mathrm{C}$ for one day to allow full sedimentation of suspended particles prior to addition of experimental macrofauna.

\subsubsection{Addition of experimental macrofauna}

Because of the large number of macrofaunal organisms added, establishment of the entire mesocosm experiment was done over three days. During these preparations, all containers were supplied with running seawater at the planned experimental temperature $\left(18\right.$ or $22^{\circ} \mathrm{C}$ ). 
Firstly, specimens of $H$. diversicolor $(\mathrm{n}=5), M$. balthica $(\mathrm{n}=7)$, and $T$. benedeni $(\mathrm{n}=20$ ) were added to each container, corresponding respectively to 280,395 and 1130 ind. $\mathrm{m}^{-2}$. Subsequently, 133 individuals of $C$. volutator (corresponding to 7500 ind. $\mathrm{m}^{-2}$ ) were added to each experimental unit by using a pipette to avoid mechanical damage of the amphipods. Finally, $133 \mathrm{H}$. ulvae $\left(7500\right.$ ind. $\mathrm{m}^{-2}$ ) scored to be uninfected were added to each of the 14 containers planned to contain less parasites. To each container planned to contain high levels of parasitism ( $\mathrm{n}=14), 38$ of the added $H$. ulvae were infected by Maritrema spp. and two by Microphallus spp., corresponding to planned infection prevalence of $30 \%$ by microphallid trematodes. The infection prevalence in Hydrobia varies greatly with locality and season, but often approaches 30\% during the active season (Field and Irwin, 1999; Jensen and Mouritsen, 1992; Kube et al., 2002). In some rare cases, the trematode prevalence in the snail population may exceed $50 \%$ and even reach 90\% (Honer, 1961; Rothschild, 1938). Moreover, the Maritrema-Microphallus ratio of 19 mirrors the in situ ratio at the time of snail collection. To avoid escape of snails from the water column, a thin layer of grease was smeared out just above the water surface inside each experimental container and renewed as needed. The densities of macrofaunal organisms eventually added to each container correspond to natural abundances previously recorded in the Danish Wadden Sea (Jensen, 1992; Mouritsen, 1994).

\subsection{Post-experimental protocol}

Because of the labour associated with the post-experimental protocol, all 28 experimental mesocosm units could not be processed within a single day. Hence, the experimental period ranged between 72 and 78 days in that one unit from each of the four treatments was processed every day. This secured that the additional variance introduced by this procedure was distributed evenly across the four experimental treatments.

At termination, the containers were carefully drained until the water surface was c. $0.5 \mathrm{~cm}$ above the sediment, ensuring that it was left undisturbed. To obtain data on the meiofauna community, five small core samples were then taken at arbitrarily chosen positions in each container on the sediment surface to a depth of $2.5 \mathrm{~cm}$ using modified plastic syringes $(\varnothing=12 \mathrm{~mm}$ ). These sediment samples were pooled together, for a total of $5.7 \mathrm{~cm}^{2}$ surface area and $14.1 \mathrm{~cm}^{3}$ sediment volume retrieved from each container. Each pooled sample was sieved through a sequence of three screens with mesh sizes of 500, 250 and $63 \mu \mathrm{m}$, respectively, and the resulting three size fractions of organisms were preserved separately in neutralized formaldehyde (4\%) (Fig. 2). This process allowed enumeration and species identification to lowest taxonomic level possible of one size fraction of macrofauna (by definition $>500 \mu \mathrm{m})$ and two size fractions of meiofauna (250-500 $\mu \mathrm{m}$ and $63-250 \mu \mathrm{m})$. Following core sampling, the remaining substrate was retrieved from each container to a depth of $2.5 \mathrm{~cm}$ and sieved through a $500 \mu \mathrm{m}$ mesh to retain and count macrofaunal species. The sifted sediment was subsequently homogenized manually and three small subsamples were collected for later analysis of particle composition, chlorophyll- $a$ content and diatom community structure. Subsamples for sediment and chlorophyll- $a$ analysis (each c. 20 g sediment) were stored in plastic bags in a freezer, whereas the sample for diatom community analysis (c. $10 \mathrm{~g}$ ) was preserved with Lugol's solution. After retrievement of sediment subsamples, the remaining substrata were sieved through a $250 \mu \mathrm{m}$ mesh to count and identify juvenile macrofaunal organisms passing the $500 \mu \mathrm{m}$ sieve (Fig. 2). After processing the surface sediment, the four $\mathrm{cm}$ of bottom sediment left in each

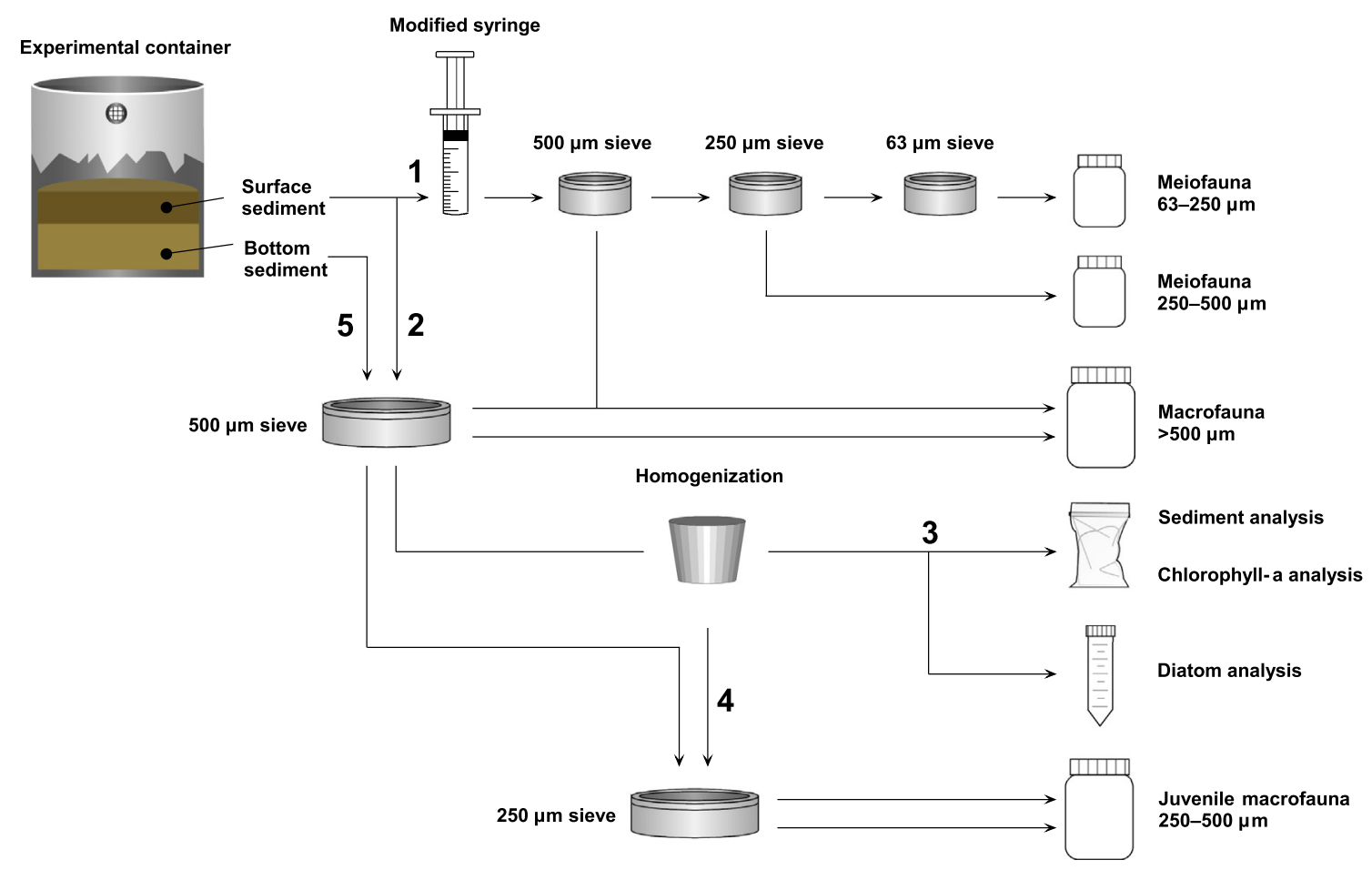

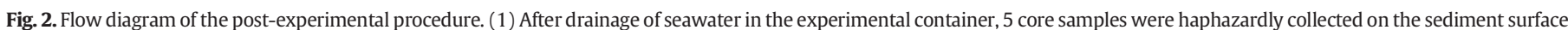

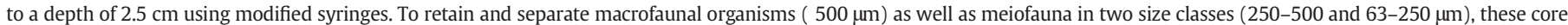

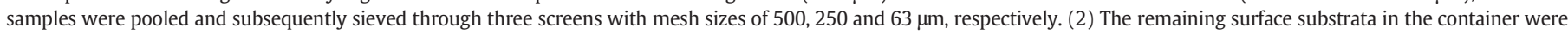

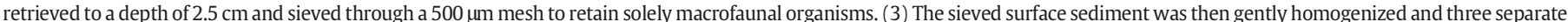

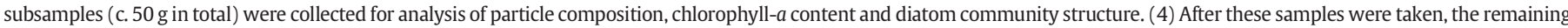

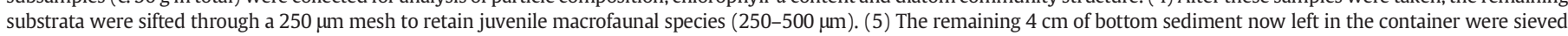
through 500 and $250 \mu \mathrm{m}$ meshes to count remaining macrofaunal species. The different elements are not to scale. See text for further details. 
container was finally sieved through 500 and then $250 \mu \mathrm{m}$ mesh in order to retrieve more deeply buried macrofauna (i.e. H. diversicolor and $M$. balthica). Hence, the post-experimental protocol resulted in the following three size fractions of animals: $>500 \mu \mathrm{m}$ (macrofauna), 250-500 $\mu \mathrm{m}$ (juvenile macrofauna and large meiofauna) and 63$250 \mu \mathrm{m}$ (small meiofauna) (Fig. 2). Before counting, the formalin preserved animals were dyed with Bengal Rose to stain individuals alive at the point of experimental termination. Macrofaunal species found in the large meiofauna fraction $(250-500 \mu \mathrm{m})$ were merged with the juvenile macrofauna fraction prior to statistical analyses. During the collection of subsamples for analyses of particle composition, chlorophyll-a content and diatom community structure, it was unavoidable to lose a fraction of juvenile macrofaunal species, which at that time were not separated from the surface sediment. Hence, we corrected for this loss for the three most abundant macrofauna species: $C$. volutator, $H$. ulvae and $T$. benedeni. The different size classes of animals were analyzed both separately and together because small and large specimens may respond differently to the experimental treatments. Prior to statistical analyses the abundance of meiofaunal organisms was converted into individuals per container.

A subsample of ten haphazardly chosen adult mud snails (those screened for parasites pre-experimentally) from each container were measured to the nearest $0.1 \mathrm{~mm}$ (apex to aperture) under a stereomicroscope to ascertain that the post-experimental shell height was similar between experimental treatments. The snails were then dissected for the presence of primary larval trematode infections to reveal possible false negative infections, and hence, departures in the planned trematode prevalence during the experiment. Also, an arbitrary subsample of surviving amphipods retained on the $250(n=14-70$ per treatment) and $500 \mu \mathrm{m}$ mesh ( $\mathrm{n}=70$ for each treatment) were measured to the nearest $0.1 \mathrm{~mm}$ (rostrum to telson) and subsequently dissected for the presence of parasites in the body cavity. This was done to obtain the post-experimental size distribution of the amphipod population and to establish the level of metacercarial infection (unencysted and encysted cercariae combined). In addition, amphipods larger than $3.0 \mathrm{~mm}$ were sexed.

\subsection{Sediment analysis}

Sediment subsamples were analyzed by means of laser-diffraction using Sympatec HELOS He-Ne laser $(632.8 \mathrm{~nm})$ and the material was prepared according to standard procedure (see Rasmussen, 2011). This protocol allowed determination of median particle diameter, sorting coefficient (see Friedman, 1962) and clay (grain size between $0-2 \mu \mathrm{m})$, silt (2-63 $\mu \mathrm{m})$ and sand $(63-2000 \mu \mathrm{m})$ content.

\subsection{Chlorophyll-a analysis}

Chlorophyll- $a$ content of substrate was measured as an indirect estimate of microphytobenthos abundance. Each sediment sample $(10 \mathrm{~g})$ was extracted for active chlorophyll- $a$ (i.e. correcting for phaephytin- $a$ content) following standard procedures (see Lorentzen, 1967; Mouritsen and Haun, 2008). Prior to the statistical analysis, the chlorophyll- $a$ concentrations were converted into $\mathrm{mg} \mathrm{m}^{-2}$.

\subsection{Diatom analysis}

To elucidate the community structure of benthic microalgae, specimens of epipelic (free-living between sediment particles) and epipsammic (attached to sediment particles) diatoms were counted and identified to lowest possible taxonomic level under a light microscope (x400). The Lugol's preserved samples were thoroughly homogenized and a small subsample of each was smeared out on a microscope slide for enumeration following the procedure by Mouritsen and Haun (2008). From these data, we calculated the relative frequency of both epipelic and epipsammic species. Epipelic and epipsammic algae were analysed separately due to the numeric dominance of the latter.

\subsection{Data analyses}

Full model two-way ANOVA was used as the main analysis to assess the effect of temperature and parasitism as well as their interaction on the density of organisms and the applied species diversity measures (see below). If the full model ANOVA demonstrated lack of significant interaction between temperature and parasitism, a reduced model ANOVA was performed with the interaction included in the error variance. Organisms whose density was influenced by temperature or parasitism in the two-way ANOVA was further modeled as a function of temperature, parasitism (binary variables) and the density of C. volutator using multiple regression. This was done to identify potential indirect community effects of parasitism and temperature stemming from changes in amphipod density isolated.

Alternatively, the data could be analyzed using a single MANOVA that includes all animal species in the experimental community as variables, thereby statistically correcting the responds of individual species for also other species present (i.e. correcting for first-order species interactions). This was not done for two reasons: (1) our main goal was to evaluate the impact of temperature and parasitism on the community as a whole, and for affected individual species separately, under influence of resulting species interactions; (2) including all animal species in one analysis critically reduce statistical power as the degrees of freedom for the error term become very low. It follows that below mentioning of isolated impact of temperature and parasitism implies impact of these fixed factors and the underlying species interactions. Problems with test performance also apply to the possibility of including other species than Corophium in the subsequent multiple regressions as this creates issues regarding overfitting and multicollinearity.

We calculated four diversity indices according to Krebs (1999): (1) Simpson's diversity index emphasizing common species ( $1 / \mathrm{D}, \mathrm{D}=$ $\sum \mathrm{p}_{\mathrm{i}}^{2}, \mathrm{p}_{\mathrm{i}}=$ proportion of species $i$ in the community), (2) ShannonWiener index emphasizing rare species $\left(2^{\mathrm{H}}, \mathrm{H}=-\sum \mathrm{p}_{\mathrm{i}} \log \mathrm{p}_{\mathrm{i}}\right)$, (3) Simpson's measure of evenness ( $1 / \mathrm{Ds}, \mathrm{s}=$ number of species in the sample), and (4) species richness (s). None of the results obtained using Shannon-Wiener index and Simpson's measure of evenness departed qualitatively from those achieved using Simpson's diversity index. Moreover, the experimental treatments did not affect species richness of the experimental organisms. Hence, we consider here only the significant results obtained using Simpson's diversity index in Results. The unit of this diversity index is 'species', which denotes the number of evenly frequent species required to generate the observed heterogeneity of the sample.

All statistical analyses were conducted using SPSS version 18.0. Parametric tests were preceded by evaluation of assumptions. If violated, data were ln-, rank- or arcsin-transformed to meet assumptions or nonparametric tests were applied. Mean values on raw data in association with standard error (SE) are given throughout although some data were transformed or subject to non-parametric testing. Crosstabs refers to two-way contingency analysis.

\section{Results}

\subsection{Sediment composition}

All sediment characteristics measured proved to be statistically unaffected by treatments (two-way ANOVA, $F_{1,25} \leq 1.948, p \geq 0.175$ for all parameters). The average median particle diameter across experimental units was $141.6 \pm 0.39 \mu \mathrm{m}$, and the relative proportion of clay, silt and sand was $1.0 \pm 0.03,7.3 \pm 0.15$ and $91.7 \pm 0.18 \%$, respectively. The mean sorting coefficient was $1.22 \pm 0.06$, indicating well-sorted substrate (Friedman, 1962). 


\subsection{Snails}

\subsubsection{Abundance}

The population of mud snails increased in all four treatments during the experiment (Fig. 3A). Because H. ulvae has a pelagic larval stage that appears unable to survive under experimental conditions (Fish and Fish, 1977a), this recruitment probably originates from meiofaunal-sized juveniles present in the added substrate from the start of the experiment that have grown to macrofaunal size. This was particularly evident at the warm temperature with low parasitism, in which the snail density increased by $37.6 \%$, suggesting that increased temperature directly or indirectly promotes juvenile recruitment (Fig. 3A). This increase was not seen at the warm temperature with high parasitism, leading to a significant temperature-parasitism interaction (two-way ANOVA, $F_{1,24}=7.949, p=0.009$; Fig. $3 \mathrm{~A}$ ). The mortality rate of the individually added adult mud snails was low (1.5\% overall), and their density did not differ among treatments at the end of the experiment (one-way ANOVA, $F_{3,24}=1.245, p=0.315$ ).
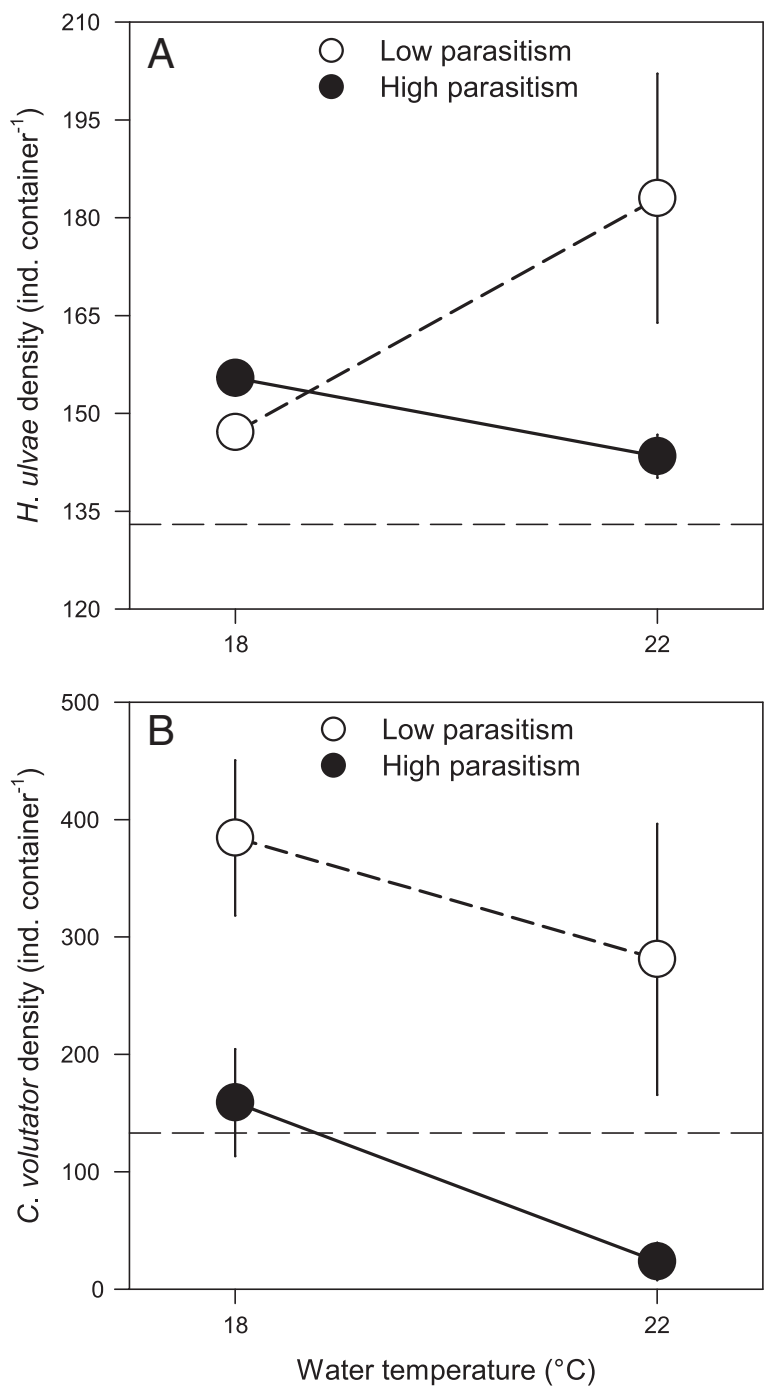

Fig. 3. The post-experimental density (mean number of ind container $^{-1} \pm \mathrm{SE}$ ) of (A) Hydrobia ulvae (all size fractions combined) and (B) Corophium volutator at $18{ }^{\circ} \mathrm{C}$ and $22{ }^{\circ} \mathrm{C}$ with low (open circles, dashed line) and high (solid circles, continuous line) level of parasitism (see Section 3.2.2 for levels). In both panels the dashed horizontal line indicates the initial number of adult mud snails $(n=133)$ and amphipods $(n=133)$ added to each experimental unit. Note that some error bars are smaller than symbols.

\subsubsection{Size and prevalence of infection}

The mean post-experimental shell-height of adult mud snails (those added experimentally) was $5.8 \pm 0.04 \mathrm{~mm}$ and did not differ between treatments (one-way ANOVA, $F_{3,276}=2.371, p=0.071$ ). Across all experimental units, the average shell-height of recruited (juvenile) snails was $2.8 \pm 0.03 \mathrm{~mm}(\mathrm{n}=723)$.

The post-experimental dissection of adult snails revealed that some individuals initially scored as uninfected were not free of microphallid parasites. This was expected as determination of parasite prevalence based on cercarial shedding does not reveal immature infections that will shed cercariae at a later point, thereby underestimating actual prevalence (Curtis and Hubbard, 1990). Averaging the observed microphallid prevalence at the start and at the end of the experiment, the approximated realized prevalence during the experiment was 3.9 and $1.9 \%$ in the low parasitism treatments and 30.6 and $31.1 \%$ in the high parasitism treatments at 18 and $22{ }^{\circ} \mathrm{C}$, respectively. The microphallid prevalence in the snail population was statistically similar at 18 and $22^{\circ} \mathrm{C}$ in both the low (Chi-square test, $\chi^{2}{ }_{1}=0.672, p=$ 0.412 ) and high (Chi-square test, $\chi^{2}{ }_{1}=0.031, p=0.861$ ) parasitism treatments.

\subsection{Amphipods}

\subsubsection{Abundance}

Recruitment occurred during the experiment in all treatments, as evidenced by presence of juveniles in the $250-500 \mu \mathrm{m}$ size fractions. Nonetheless, the overall post-experimental abundance of $C$. volutator was negatively affected by both elevated levels of parasitism and increased temperature, resulting in an almost eradication of amphipods at the warm temperature with high parasitism (two-way ANOVA, parasitism: $F_{1,25}=16.279, p<0.0005$; temperature: $F_{1,25}=10.296$, $p=0.004$; Fig. 3B). The density of amphipods decreased by $82.3 \%$ (contrast to initial density) at $22{ }^{\circ} \mathrm{C}$ with high parasitism, was less affected at $18{ }^{\circ} \mathrm{C}$ with high parasitism (19.4\% increase), and increased considerably at $18{ }^{\circ} \mathrm{C}(188.3 \%)$ and $22{ }^{\circ} \mathrm{C}(111.3 \%)$ with low parasitism.

\subsubsection{Infection intensity}

The post-experimental metacercarial infection intensity generally increased with the size of the amphipods retained on the $500 \mu \mathrm{m}$ mesh. One-way analysis of unstandardized residuals from an intensity-size regression across the entire material demonstrated that the sizecorrected metacercarial infection intensity differed significantly between treatments from $0.15 \pm 0.03\left(18{ }^{\circ} \mathrm{C}\right.$, low parasitism) over $1.33 \pm 0.21\left(18{ }^{\circ} \mathrm{C}\right.$, high parasitism) and $2.08 \pm 0.24\left(22{ }^{\circ} \mathrm{C}\right.$, low parasitism) to $3.35 \pm 0.41\left(22^{\circ} \mathrm{C}\right.$, high parasitism) metacercariae per mm amphipod (Kruskal-Wallis test, $\chi^{2}{ }_{3}=137.0, p<0.0005, \mathrm{n}=280$ ). Post hoc multiple comparisons showed significant differences between all treatments $(p \geq 0.028)$. The highest metacercarial load recorded in an individual was 82 found at the warm temperature with high parasitism. Metacercarcial infections in amphipods in the $250-$ $500 \mu \mathrm{m}$ size fraction were rare: the overall infection prevalence was $5.4 \%$ and the mean infection intensity was $0.08 \pm 0.03$ metacercariae per amphipod $(\mathrm{n}=224)$.

\subsection{Faunal community structure - abundance}

Twenty-three taxa of benthic animals (meio- and macrofauna) were recorded (see Supplement 1). Harpacticoid copepods (relative frequency: $40 \%$ ), foraminifera (36\%) and nematodes (13\%) numerically dominated the meiofaunal community. In particular, Ammonia sp. (Foraminifera) and Harpacticoid sp. 2 (Copepoda) was abundant. As expected, $C$. volutator and $H$. ulvae dominated the macrozoobenthic community. Encountered macrofaunal species other than those added (see Section 2.3) originate from meiofaunal-sized juveniles present in the applied natural substrata. 
Apart from C. volutator, eight species were significantly affected either positively or negatively by temperature (Table 1 , two-way ANOVA), corresponding to c. $36 \%$ of all species. Parasitism had no statistically significant effect on these non-host organisms (two-way ANOVA, $F_{1,25} \leq 3.462, p \geq 0.075$ ). The foraminifera Elphidium williamsoni and the spionid polychaete Polydora ligni particularly responded negatively to increased temperature (68-75\% reduction). By contrast, increased temperature had a notable positive effect on the density of Harpacticoid sp. 3 in the $63-250 \mu \mathrm{m}$ size class and the sabellid polychaete Manayunkia aestuarina (71-89\% increase). Subsequent multiple regressions including the abundance of each of the eight faunal species as response variable and temperature, parasitism and the abundance of $C$. volutator as predictors, demonstrated lack of an isolated significant effect of temperature on Leptocythere sp. and T. benedeni (Table 1). This suggests that the temperature-effect on the abundance of these two species to some extend is driven by their relationship to the also temperature-affected C. volutator. Albeit statistically insignificant per se, Corophium abundance explains 88 and $46 \%$ of the variance explained by temperature isolated (Table 1 ). The polychates $H$. diversicolor and $P$. ligni were the only species significantly influenced by Corophium abundance isolated, which explains $19-24 \%$ of the variation (Table 1, multiple regression). After correcting for this amphipod impact, the significant negative effect of increased temperature on these worms is retained. Hence, the isolated effect of both elevated temperature and amphipod abundance combine to determine their post-experimental densities. Of these two factors, temperature appears to matter the most as judged from the partial $r$-ratios: Corophium explains c. 16\% (Hediste) and 65\% (Polydora) of the variance explained by temperature (Table 1 ).

Increased level of parasitism positively influenced the density of two meiofaunal species in the $250-500 \mu \mathrm{m}$ size class (Table 1 , two-way ANOVA; Fig. 4): Haynesina germanica (Foraminifera) and Protohydra leuckarti (Hydrozoa) (49-59\% increase). Temperature had no significant effect on the abundance of these two species (two-way ANOVA, $F_{1,25} \leq$ $1.667, p \geq 0.208$ ). Post-hoc multiple regressions showed no significant effect of Corophium abundance on the two meiofaunal species. Amphipods explain only $1-2 \%$ of the variance, corresponding to about a tenth of the variance explained by parasitism (Table 1 ). In the case of $P$. leuckarti, however, correcting for this rather small Corophium contribution manages to turn the significant isolated impact of parasitism just insignificant ( $p=0.073$, see Table 1 ). Statistically, these findings suggest that parasitism has an impact on $H$. germanica that is not indirectly governed by Corophium abundance, whereas this amphipod plays a role in generating the significant parasite effect on P. leuckarti.
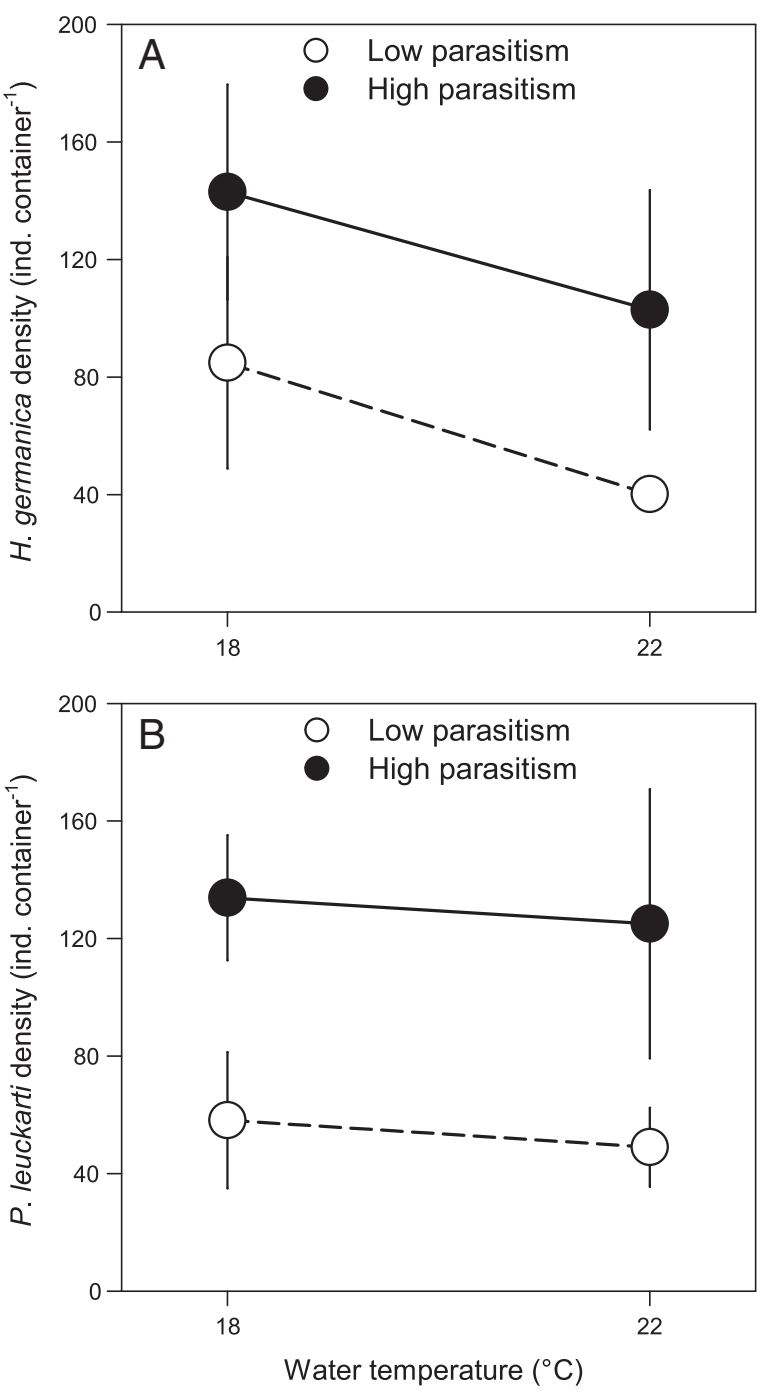

Fig. 4. Non-host benthic fauna affected solely by parasitism. The density (mean number of ind. container ${ }^{-1} \pm$ SE, size class: $250-500 \mu \mathrm{m}$ ) of (A) Haynesina germanica (Foraminifera) and (B) Protohydra leuckarti (Hydrozoa) at $18{ }^{\circ} \mathrm{C}$ and $22^{\circ} \mathrm{C}$ with low (open circles, dashed line) and high (solid circles, continuous line) levels of parasitism (see Section 3.2.2 for levels). Note that some error bars are smaller than symbols.

Table 1

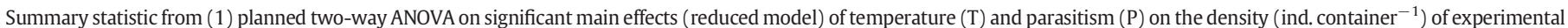

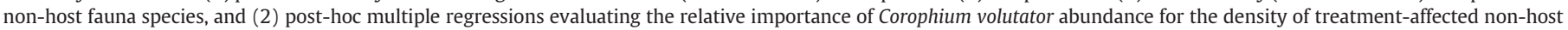

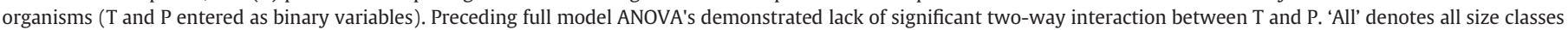

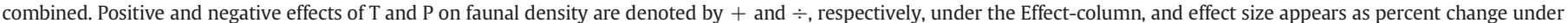

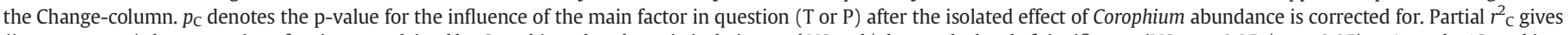

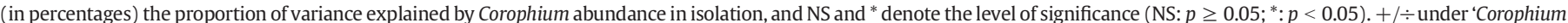

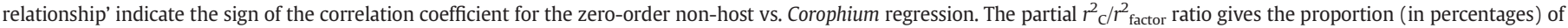
variance explained by Corophium abundance relative to the main factor (T or P). Fo: foraminifera, Po: polychaeta, Os: ostracoda, Co: copepoda, Hy: hydrozoa, Ol: oligochaeta.

\begin{tabular}{|c|c|c|c|c|c|c|c|c|c|c|}
\hline \multirow[b]{2}{*}{ Taxon } & \multicolumn{6}{|c|}{ Two-way ANOVA } & \multicolumn{4}{|c|}{ Post-hoc multiple regression } \\
\hline & Size class & Factor & Effect & Change (\%) & $F_{1,25}$ & $p$ & $p_{\mathrm{C}}$ & Partial $r_{\mathrm{C}}^{2}(\%)$ & Corophium relationship & Partial $r_{\mathrm{c}}^{2} / r_{\text {factor }}^{2}$ ratio (\%) \\
\hline \multicolumn{11}{|l|}{ Meiofauna } \\
\hline Elphidium williamsoni (Fo) & All & $\mathrm{T}$ & $\div$ & 74.9 & 28.492 & $<0.0005$ & $<0.0005$ & $0.05^{\mathrm{NS}}$ & + & 0.12 \\
\hline Manayunkia aestuarina (Po) & All & $\mathrm{T}$ & + & 88.7 & 9.158 & 0.006 & 0.044 & $2.16^{\mathrm{NS}}$ & $\div$ & 13.57 \\
\hline Leptocythere sp. (Os) & All & $\mathrm{T}$ & $\div$ & 40.9 & 6.920 & 0.014 & 0.190 & $6.15^{\mathrm{NS}}$ & + & 87.57 \\
\hline Harpacticoid sp. 2 (Co) & All & $\mathrm{T}$ & $\div$ & 56.4 & 8.946 & 0.006 & 0.014 & $0.83^{\mathrm{NS}}$ & + & 3.56 \\
\hline Harpacticoid sp. 3 (Co) & $63-250 \mu \mathrm{m}$ & $\mathrm{T}$ & + & 70.8 & 4.963 & 0.035 & 0.022 & $4.37^{\mathrm{NS}}$ & + & 21.86 \\
\hline Haynesina germanica (Fo) & $250-500 \mu \mathrm{m}$ & $\mathrm{P}$ & + & 49.1 & 4.631 & 0.041 & 0.042 & $2.02^{\mathrm{NS}}$ & + & 12.50 \\
\hline Protohydra leuckarti (Hy) & $250-500 \mu \mathrm{m}$ & $\mathrm{P}$ & + & 58.6 & 7.327 & 0.012 & 0.073 & $1.25^{\mathrm{NS}}$ & $\div$ & 9.79 \\
\hline \multicolumn{11}{|l|}{ Macrofauna } \\
\hline Hediste diversicolor $(\mathrm{Po})$ & All & $\mathrm{T}$ & $\div$ & 27.5 & 14.305 & 0.001 & 0.046 & $24.11^{*}$ & + & 15.60 \\
\hline Polydora ligni (Po) & All & $\mathrm{T}$ & $\div$ & 68.4 & 5.462 & 0.028 & 0.004 & $19.35^{*}$ & $\div$ & 64.91 \\
\hline Tubificoides benedeni $(\mathrm{Ol})$ & All & $\mathrm{T}$ & + & 12.6 & 4.691 & 0.040 & 0.103 & $4.93^{\mathrm{NS}}$ & $\div$ & 46.09 \\
\hline
\end{tabular}




\subsection{Faunal community structure - diversity}

At community level, Simpson's diversity index for macrofaunal organisms (C. volutator excluded, all size classes combined) was affected differently by parasitism depending on the experimental temperature (two-way ANOVA, temperature $\times$ parasitism interaction: $F_{1,24}=$ $11.727, p=0.002$; Fig. 5). Whereas the macrofaunal diversity decreased (7\%) with increased temperature in the low parasitism treatments, it increased (5\%) with temperature in the high parasitism treatments. Hence, the indirect effect of increased parasitism mitigates the negative influence of elevated temperature on the diversity of the non-host faunal community.

\subsection{Chlorophyll-a content and diatom community structure}

As a measure of benthic microalgae abundance, the chlorophyll- $a$ content in the substrata was not significantly affected by treatments (two-way ANOVA, $F_{1,24} \leq 1.404, p \geq 0.247$ ). The overall pattern was an increase $(8 \%)$ with temperature, whereas increased parasitism tended to affect the chlorophyll- $a$ concentration negatively. Moreover, the chlorophyll- $a$ concentration was not significantly related to the abundance of $C$. volutator (multiple regression, $p=0.318$ ). The grand mean chlorophyll- $a$ content in the sediment was $595.5 \pm 34.3 \mathrm{mg} \mathrm{m}^{-2}$, corresponding well to previous recorded summer levels in the Danish Wadden Sea (see Mouritsen et al., 1998).

Seventeen species of epipelic (pennales and centrales combined) and four species of epipsammic microalgae were recorded (see Supplement 2). Although differences were small quantitatively, the relative frequency of the 17 epipelic diatom species differed significantly between experimental treatments (Crosstabs, all experimental units together: $\left.\chi^{2}{ }_{48}=101.2, p<0.0005\right)$. However, analyses of individual species showed that only one species (Brockmanniella sp.) were significantly affected (positively) by increased parasitism, and that this epipelic diatom was not related to the abundance of $C$. volutator (Supplement 2). The relative frequency of the epipsammic diatom species also differed among treatments (Crosstabs, all experimental units together: $\chi^{2}{ }_{9}=86.1, p<0.0005$; Supplement 2). Neither temperature or parasitism, however, had an impact on any of the four epipsammic diatom species (two-way ANOVA, $F_{1,25} \leq 0.930, p \geq 0.344$ ).

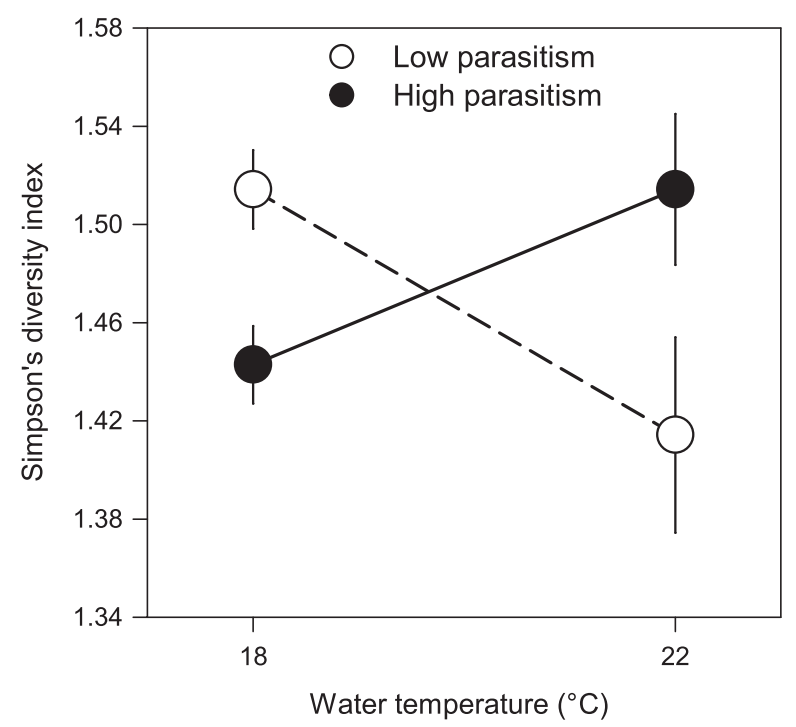

Fig. 5. Simpson's diversity index (1/D) for macrofaunal species (exclusive Corophium volutator, all sizes combined) at $18{ }^{\circ} \mathrm{C}$ and $22^{\circ} \mathrm{C}$ with low (open circles, dashed line) and high (solid circles, continuous line) levels of parasitism. The y-axis unit is species. Values are means \pm SE. See Supplement 1 for a species list of macrofaunal organisms.
None of the applied diversity measures (see Section 2.9) on the microphytobenthos community were significantly affected by experimental treatments (two-way ANOVA, $F_{1,25} \leq 0.614, p \geq 0.441$ ).

\section{Discussion}

Although the synergistic effect of parasitism and climate warming previously has been emphasized as potentially important to host population dynamics and community structure (e.g. Brooks and Hoberg, 2007; Harvell et al., 2002; Marcogliese, 2001, 2008; Mouritsen and Poulin, 2002b; Poulin and Mouritsen, 2006), no studies have yet shown that such temperature-parasitism synergism may alter softbottom communities indirectly, partly through density regulation of a functionally important community member. However, the present results demonstrate unequivocally that parasitism and elevated temperature can be a critical combination for the population size of the intertidal ecosystem engineer $C$. volutator, and that this parasiteinduced amphipod regulation governed by temperature may result in significant changes to the surrounding benthic community structure.

\subsection{Amphipods}

Both increased temperature and parasitism had a negative impact on the density of $C$. volutator, but the combined effect of these two parameters was particularly detrimental, leading to an almost complete extinction of the experimental amphipod population at the warm temperature with high parasitism (Fig. 3B). It is notable that this temperature-parasitism synergy resulted in negative population growth in the high temperature/high parasitism treatment, whereas the amphipod population increased or reached equilibrium in the remaining treatments. The reduced amphipod density seen at the high temperature can be explained by the fact that emergence of infective trematode stages (cercariae) from the first intermediate snail host is a strong positive function of temperature up to an optimum temperature (Meissner and Bick, 1999a; Mouritsen, 2002; Mouritsen and Jensen, 1997), as demonstrated also in other amphipod-trematode associations (Studer and Poulin, 2013; Studer et al., 2010). Hence, the intensitydependent parasite-induced Corophium mortality generally increases as temperature rises (Jensen and Mouritsen, 1992; Meissner and Bick, 1999a,b; Mouritsen and Jensen, 1997; Mouritsen et al., 2005), thereby also affecting recruitment. The combined influence of increased temperature and parasitism may therefore also partly explain the lower abundance of amphipods in the warm relative to the cold temperature treatments with low parasitism (Fig. 3B). Although the microphallid prevalence in the mud snail population among these treatments was rather similar (1.9 and 3.9\%, respectively), we found marked difference in the number of parasites in the amphipods body cavity: mean infection intensity was 0.15 and 2.08 metacercariae per mm amphipod at 18 and $22{ }^{\circ} \mathrm{C}$, respectively. This finding emphasizes the importance of temperature per se for the transmission rate of larval trematodes from mud snails to amphipods, and in turn intensity-dependent amphipod mortality (Mouritsen and Jensen, 1997; Studer et al., 2010). Note that infection intensities of surviving amphipods only is an indicator of parasite pressure/transmission as individuals that have died from heavy parasite burdens are not included.

\subsection{Faunal community}

\subsubsection{Effect of temperature}

The density of eight species, together representing a variety of taxa and feeding types, changed significantly with increased temperature (Table 1): five species were negatively affected whereas three species responded positively. Although the processes causing these species specific temperature responses remain unclear, it emphasizes that temperature changes may indeed impact the overall community structure of benthic animals in the soft-bottom intertidal (Reise and van 
Beusekom, 2008). Some of the temperature-effects, however, appear indirect by acting in part through changes in the also temperaturedependent Corophium abundance. This applies to the responses of the ostracod Leptocythere sp., the oligochate T. benedeni and particularly so to the polychates $H$. diversicolor and $P$. ligni (see Table 1 ). The abundance of the latter two species was clearly not solely influenced by temperature per se but also Corophium abundance. Hediste diversicolor was positively associated with the amphipod density, and because this omnivorous polychaete occasionally feeds on C. volutator (Jensen and André, 1993; Muus, 1967; Ólafsson and Persson, 1986), the amphipods may have served as a supplementary food source for $H$. diversicolor in the present study, in turn affecting their survival positively. In contrast, the abundance of $P$. ligni was negatively related to the density of $C$. volutator. Disturbance caused by amphipod burrowing could be one factor responsible for this negative relationship as spionids, including Polydora, are sensitive to bioturbation (Flach, 1996; Volkenborn et al., 2009). Because the abundance of $C$. volutator is strongly affected by the combined effect of elevated parasitism and temperature, the link between amphipods and the above two polychaetes predicts that parasitism also participates indirectly in regulating the abundance of these worms. Statistically, however, our experiment failed to demonstrate an isolated effect of parasitism on $\mathrm{H}$. diversicolor and P. ligni.

\subsubsection{Effect of parasitism and temperature-parasite interaction}

The density of mud snails H. ulvae was influenced by the combined effect of temperature and parasitism: while the density was roughly unaffected by temperature in the high parasite treatments, it was considerably higher in the warmest treatment of those with low parasitism (Fig. 3A). Because the abundance of the experimentally added adult snails was unchanged, the pattern was due to a particularly high recruitment success of juveniles at the warm temperature with low parasitism. Although the exact mechanisms behind this pattern remain unknown, it can easily be envisaged that temperature affects the development and survival of newly settled snails directly (Fish and Fish, 1977b). On the other hand, microphallid cercariae especially present in the high parasitism treatments do not infect hydrobiids of any age, and the absence of a positive effect of increased temperature in the high parasitism treatment suggests an indirect negative influence of increased parasitism. For instance through modified interaction cascades stemming from the overall changed community structure observed. In any case, the finding indicates that temperature and parasitism together may play a role in determining the recruitment success of mud snails.

The abundance of larger individuals of the foraminifera $\mathrm{H}$. germanica and the polyp $P$. leuckarti was positively affected by elevated parasitism (Table 1; Fig. 4). These two meiofaunal species were respectively unaffected or very weakly affected by Corophium abundance, suggesting that parasitism benefits their population sizes through processes other than the potentially positive effects of parasite-induced reduction in amphipod density. The hemi-sessile P. leuckarti is a predator known to feed on a wide spectrum of meiofaunally sized organisms (Giere, 1993; Muus, 1967), and trematode larvae (cercariae) released from infected mud snails might have served as an additional food source to the polyps as also found in other systems (Køie, 1975; Thieltges et al., 2008). This could reasonably explain higher densities of $P$. leuckarti in high parasitism treatments due to increased survival or reproduction. Furthermore, when the cercariae die they are subject to bacterial degradation on the sediment surface. Assuming that $H$. germanica feeds on bacteria associated with such degradation (see Ward et al., 2003), the mere presence of cercariae in the high parasitism treatments could contribute to the greater population size of these foraminifera. Such interpretation, however, requires that other processes regulate the abundance of the two meiofaunal species at the warm temperature with high parasitism where the abundance of released cercariae is at its maximum.
In terms of species diversity, the faunal community as a whole appeared unaffected by experimental treatments. However, focusing on the macrofaunal community without amphipods, and hence the part of the community not directly targeted by microphallid trematodes, we see a small but significant increase in diversity with temperature in the high parasite treatment, as opposed to a decrease with temperature in the low parasite treatment (Fig. 5). This intriguing result emphasizes two important points about the impact of trematodes on zoobenthic communities: (1) Through indirect interactions cascades, the influence of parasites reach beyond the host species involved in their life-cycle, and (2) elevated parasitism acts to mitigate the overall tendency of a negative impact on resident benthic diversity by increased temperatures (Harley et al., 2006; Schückel and Kröncke, 2013 and references therein), even turning it to a positive effect. By doing so, sufficiently high levels of parasitism may in fact serve to maintain diversity at increasing temperatures, in turn stabilizing the macrozoobenthic community as species diversity generally correlates with community stability (e.g. McCann, 2000).

\subsection{Chlorophyll-a content}

The chlorophyll- $a$ content in the substrata was found statistically unaffected by experimental treatments. This is surprising because substantial evidence exists that $C$. volutator, whose density was severely affected by treatments, can significantly regulate the density of benthic diatoms on which they feed (e.g. Gerdol and Hughes, 1994b). In general, authors report a negative relationship between the presence of C. volutator and chlorophyll-a concentration (Coles, 1979; Daborn et al., 1993; Gerdol and Hughes, 1994a; Hagerthey et al., 2002). For instance, Gerdol and Hughes (1994a) demonstrated that experimental removal of $C$. volutator on an intertidal mudflat led to increased chlorophyll- $a$ levels in the sediment, suggesting that the amphipods exert a top-down control on the diatom community, even at densities as low as 9000 individuals $\mathrm{m}^{-2}$. However, in the present mesocosm experiment the abundance of benthic algae was numerically lower (albeit non-significant) in the high parasite treatments (low amphipod density) and no overall relationship was found between the density of amphipods and chlorophyll-a levels across all experimental units. More complex interaction cascades between temperature, varying densities of infected mud snails (see Mouritsen and Haun, 2008) and other grazing and bioturbating experimental organisms (Dyson et al., 2007; Figs. 3A, 4 and 5; Table 1; Supplement 1), might have counteracted the otherwise expected positive effect of reduced C. volutator abundance on the benthic primary producers.

\subsection{Diatom community structure}

As opposed to diatom abundance, the overall frequency distribution of both epipelic and epipsammic diatom species differed between treatments, emphasizing that temperature and parasitism can alter the structure of intertidal microalgae communities (Supplement 2). Regarding the temperature effect, previous studies have highlighted temperature as a key abiotic factor determining the structure of benthic diatom assemblages (e.g. Hagerthey et al., 2002). It is therefore surprising that none of the recorded diatom species were significantly affected by the experimental temperature increase of four degrees. As to the impact of parasitism, there may be several ways in which the diatom community could be affected. For instance, Mouritsen and Haun (2008) showed that trematode-mediated reduction in bioturbation activity of mud snails significantly changed the structure of an intertidal community of microphytobenthos. The epipelic Brockmanniella sp. was the only species whose density was significantly affected (positively) by increased parasitism (Supplement 2). Because this epipelic diatom was not associated with amphipod abundance, the positive effect of elevated parasitism could emerge as a result of reduced bioturbation activity of infected snails. Quantitatively, however, we found only rather small 
changes of the diatom community structure in response to temperature and parasitism regardless of substantial changes in the abundance of a range of grazers (Table 1; Fig. 3 ). Thus, as seen also in the abundance data, the diatom community structure appear surprisingly resilient to our experimental treatments.

\section{Conclusion}

Our results demonstrate that microphallid trematodes affect the density of the coastal amphipod $C$. volutator in a highly temperaturedependent manner. Specifically, we found that even a relatively small increase in water temperature $\left(4^{\circ} \mathrm{C}\right)$ when combined with elevated parasitism had devastating consequences for amphipod population size. This cooperates well with both field observations and model simulations of the topical host-parasite system, together emphasizing that moderately warmer ambient temperature, for instance in light of future climate scenarios, will likely increase parasite-induced amphipod mortality and the frequency of local population crashes (Jensen and Mouritsen, 1992; Mouritsen et al., 2005).

Beyond the amphipods directly targeted by the parasites, it is notable that the structure of the surrounding benthic community of plants and animals changed as a consequence of our experimental treatments. The interaction between temperature and parasitism in the case of macrozoobenthic diversity is of particular interest here, as it shows that increased parasitism serves to eliminate the overall negative impact of a higher temperature on diversity. It is also notable that the community of primary producers, as opposed to the animals, was both quantitatively and structurally relatively unaffected. This corresponds in part with field observations during a temperature mediated parasite-induced collapse in the Wadden Sea (Mouritsen et al., 1998), and suggests that ecosystem functioning in terms of primary production is robust towards perturbations following from temperature and parasite mediated regulation of the zoobenthic community.

Our objective was to determine the community structural consequences of altered temperature and parasitism rather than to identify underlying mechanism causing them. However, the present analyses do suggest that although temperature and parasitism had direct influence, indirect processes are also involved. Of those, interaction cascades stemming from parasite-induced changes in amphipod abundance may be particularly important. In any case, the responses of the experimental organisms to temperature and parasitism appear species as well as size specific rather than coordinated.

Is this pattern evident also in situ? The experimental setup did not allow for immigration of benthic organism and emigration form the containers were constrained. Hence, the observed changes in the density of individual species and community structure emerged almost exclusively as a result of mortality and recruitment. Furthermore, because the experimental design did not allow establishment of zooand phytoplankton communities, it was not possible to integrate benthic-pelagic coupling that works under natural conditions. Finally, even small differences in the initial composition of the benthic communities among the experimental units may have developed during the course of the experiment, resulting in increased variance at the end of the experiment (founder effect). However, small-scale experiments have increasingly been recognized as a useful approach for elucidating ecosystem responses to environmental factors, including climate change (Benton et al., 2007; Stewart et al., 2013), and in the present mesocosm experiment we have attempted to optimize natural conditions. Moreover, the drawbacks identified above may for the most part contribute to blur rather than overemphasize treatment impact. Hence, our study suggests that climate-parasitism synergy can have significant repercussions for density regulation of $C$. volutator and the associated intertidal soft-bottom community.

Supplementary data to this article can be found online at http://dx. doi.org/10.1016/j.jembe.2014.06.011.

\section{Acknowledgements}

We wish to thank I. Buss, L. Flensborg, P. Mortensen and S.V. Pedersen for technical assistance. T. Cedhagen and J.J. Jonstrup are acknowledged for identification of benthic foraminifera and diatoms, respectively. We greatly appreciate the effort of J.L. Jørgensen in the field. The study was supported financially by a grant from WWF/ Novozymes (to KNM). [ST]

\section{References}

Benton, T.G., Solan, M., Travis, J.M.J., Sait, S.M., 2007. Microcosm experiments can inform global ecological problems. Trends Ecol. Evol. 22, 516-521.

Brooks, D.R., Hoberg, E.P., 2007. How will global climate change affect parasite-host assemblages? Trends Parasitol. 23, 571-574.

Christensen, O.B., Christensen, J.H., Machenhauer, B., Botzet, M., 1998. Very highresolution regional climate simulations over Scandinavia-present climate. J. Clim. 11, 3204-3229.

Christensen, J.H., Räisänen, J., Iversen, T., Bjørge, D., Christensen, O.B., Rummukainen, M. 2001. A synthesis of regional climate change simulations - a Scandinavian perspective. Geophys. Res. Lett. 28, 1003-1006.

Coles, S.M., 1979. Benthic microalgal populations on intertidal sediments and their role as precursors to saltmarsh development. In: Jeffries, R.L., Davey, A.J. (Eds.), Ecological processes in coastal environments. Blackwell Scientific Publications, Oxford, pp. 25-42.

Curtis, L.A., Hubbard, K.M., 1990. Trematode infections in a gastropod host misrepresented by observing shed cercariae. J. Exp. Mar. Biol. Ecol. 143, 131-137.

Daborn, G.R., Amos, C.L., Brylinsky, M., Christian, H., Drapeau, G., Faas, R.W., Grant, J., Long, B., Paterson, D.M., Perillo, G.M.E., Piccolo, M.C., 1993. An ecological cascade effect: migratory birds affect stability of intertidal sediments. Limnol. Oceanogr. 38, 225-231.

Deblock, S., 1980. Inventaire des trématodes larvaires parasites des mollusques Hydrobia (Prosobranches) des côtes de France. Parassitologia 22, 1-105 (in French).

Dyson, K.E., Bulling, M.T., Solan, M., Hernandez-Milian, G., Raffaelli, D.G., White, P.C.L., Paterson, D.M., 2007. Influence of macrofaunal assemblages and environmental heterogeneity on microphytobenthic production in experimental systems. Proc. $R$. Soc. B 274, 2547-2554.

Field, L.C., Irwin, S.W.B., 1999. Digenean larvae in Hydrobia ulvae from Belfast Lough (Northern Ireland) and the Ythan Estuary (north-east Scotland). J. Mar. Biol. Assoc. UK 79, 431-435.

Fish, J.D., Fish, S., 1977a. The veliger larva of Hydrobia ulvae with observations on the veliger of Littorina littorea (Mollusca: Prosobranchia). J. Zool. 182, 495-503.

Fish, J.D., Fish, S., 1977b. The effects of temperature and salinity on the embryonic development of Hydrobia ulvae (Pennant). J. Mar. Biol. Assoc. UK 57, 213-218.

Flach, E.S., 1996. The influence of the cockle, Cerastoderma edule, on the macrozoobenthic community of tidal flats in the Wadden Sea. Mar. Ecol. 17, 87-98.

Friedman, G.D., 1962. On sorting, sorting coefficients, and the lognormality of the grainsize distribution of sandstones. J. Geol. 70, 737-753.

Gerdol, V., Hughes, R.G., 1994a. Effect of Corophium volutator on the abundance of benthic diatoms, bacteria and sediment stability in two estuaries in southeastern England. Mar. Ecol. Prog. Ser. 114, 109-115.

Gerdol, V., Hughes, R.G., 1994b. Feeding behaviour and diet of Corophium volutator in an estuary in southeastern England. Mar. Ecol. Prog. Ser. 114, 103-108.

Giere, O., 1993. Meiobenthology: the microscopic fauna in aquatic sediments. SpringerVerlag, Berlin.

Hagerthey, S.E., Defew, E.C., Paterson, D.M., 2002. Influence of Corophium volutator and Hydrobia ulvae on intertidal benthic diatom assemblages under different nutrient and temperature regimes. Mar. Ecol. Prog. Ser. 245, 47-59.

Harley, C.D.G., Hughes, A.R., Hultgren, H.M., Miner, B.G., Sorte, C.J.B., Thornber, C.S. Rodriguez, L.F., Tomanek, L., Willams, S.L., 2006. The impact of climate change in coastal marine systems. Ecol. Lett. 9, 228-241.

Harvell, C.D., Kim, K., Burkholder, J.M., Colwell, R.R., Epstein, P.R., Grimes, D.J., Hofmann, E. E., Lipp, E.K., Osterhaus, A.D.M.E., Overstreet, R.M., Porter, J.W., Smith, G.W., Vasta, G. R., 1999. Emerging marine diseases - climate links and anthropogenic factors. Science 285, 1505-1510.

Harvell, C.D., Mitchell, C.E., Ward, J.R., Altizer, S., Dobson, A.P., Ostfeld, R.S., Samuel, M.D., 2002. Climate warming and disease risks for terrestrial and marine biota. Science 296, 2158-2162.

Honer, M.R., 1961. Some observations on the ecology of Hydrobia stagnorum (Gmelin) and H. ulvae (Pennant), and the relationship ecology-parasitofauna. Basteria 25, 17-29.

Jensen, K.T., 1992. Macrozoobenthos on an intertidal mudflat in the Danish Wadden Sea: comparisons of surveys made in the 1930s, 1940s and 1980s. Helgol. Meeresun. 46, 363-376.

Jensen, K.T., André, C., 1993. Field and laboratory experiments on interactions among an infaunal polychaete, Nereis diversicolor, and two amphipods, Corophium volutator \& C. arenarium: effects on survival, recruitment and migration. J. Exp. Mar. Biol. Ecol. 168, 259-278.

Jensen, K.T., Mouritsen, K.N., 1992. Mass mortality in two common soft-bottom invertebrates, Hydrobia ulvae and Corophium volutator - the possible role of trematodes. Helgol. Meeresun. 46, 329-339.

Jones, C.G., Lawton, J.H., Shachak, M., 1997. Positive and negative effects of organisms as physical ecosystem engineers. Ecology 78, 1946-1957.

Køie, M., 1975. On the morphology and life-history of Opechona bacillaris (Molin, 1859) Looss, 1907 (Trematoda, Lepocreadiidae). Ophelia 13, 63-86. 
Krebs, C.J., 1999. Ecological methodology, 2nd ed. Addison-Wesley Educational Publishers, Menlo Park, California.

Kube, S., Kube, J., Bick, A., 2002. Component community of larval trematodes in the mudsnail Hydrobia ventrosa: temporal variations in prevalence in relation to host life history. J. Parasitol. 88, 730-737.

Larsen, M.H., Jensen, K.T., Mouritsen, K.N., 2011. Climate influences parasite-mediated competitive release. Parasitology 138, 1436-1441.

Lorentzen, C.J., 1967. Determination of chlorophyll and pheo-pigments: spectrophotometric equations. Limnol. Oceanogr. 12, 343-346.

Marcogliese, D.J., 2001. Implications of climate change for parasitism of animals in the aquatic environment. Can. J. Zool. 79, 1331-1352.

Marcogliese, D.J., 2008. The impact of climate change on the parasites and infectious diseases of aquatic animals. Rev. Sci. Tech. 27, 467-484.

McCann, K.S., 2000. The diversity - stability debate. Nature 405, 228-233.

Meissner, K., Bick, A., 1999a. Laboratory studies of parasite transmission aspects between Hydrobia spp. (Gastropoda) and Corophium volutator (Amphipoda). Int. Rev. Hydrobiol. 84, 61-72.

Meissner, K., Bick, A., 1999b. Mortality of Corophium volutator (Amphipoda) caused by infestation with Maritrema subdolum (Digenea, Microphallidae) - laboratory studies. Dis. Aquat. Org. 35, 47-52.

Minchella, D.J., Scott, M.E., 1991. Parasitism: a cryptic determinant of animal community structure. Trends Ecol. Evol. 6, 250-254.

Mouritsen, K.N., 1994. Day and night feeding in Dunlins Calidris alpina: choice of habitat, foraging technique and prey. J. Avian Biol. 25, 55-62.

Mouritsen, K.N., 2002. The Hydrobia ulvae - Maritrema subdolum association: influence of temperature, salinity, light, water-pressure and secondary host exudates on cercaria emergence and longevity. J. Helminthol. 76, 341-347.

Mouritsen, K.N., Haun, S.C.B., 2008. Community regulation by herbivore parasitism and density: trait-mediated indirect interactions in the intertidal. J. Exp. Mar. Biol. Ecol. 367, 236-246.

Mouritsen, K.N., Jensen, K.T., 1997. Parasite transmission between soft-bottom invertebrates: temperature mediated infection rates and mortality in Corophium volutator. Mar. Ecol. Prog. Ser. 151, 123-134.

Mouritsen, K.N., Poulin, R., 2002a. Parasitism, community structure and biodiversity in intertidal ecosystems. Parasitology 124, S101-S117.

Mouritsen, K.N., Poulin, R., 2002b. Parasitism, climate oscillations and the structure of natural communities. Oikos 97, 462-468.

Mouritsen, K.N., Mouritsen, L.T., Jensen, K.T., 1998. Change of topography and sediment characteristics on an intertidal mud-flat following mass-mortality of the amphipod Corophium volutator. J. Mar. Biol. Assoc. UK 78, 1167-1180.

Mouritsen, K.N., Tompkins, D.M., Poulin, R., 2005. Climate warming may cause a parasiteinduced collapse in coastal amphipod populations. Oecologia $146,476-483$.

Muus, B.J., 1967. The fauna of Danish estuaries and lagoons: distribution and ecology of dominating species in the shallow reaches of the mesohaline zone. Medd. Dan. Fisk. Havunders. 5, 1-316.

Ólafsson, E.B., Persson, L.E., 1986. The interaction between Nereis diversicolor O.F. Müller and Corophium volutator Pallas as a structuring force in a shallow brackish sediment. J. Exp. Mar. Biol. Ecol. 103, 103-117.
Pihl, L., 1985. Food selection and consumption of mobile epibenthic fauna in shallow marine areas. Mar. Ecol. Prog. Ser. 22, 169-179.

Poulin, R., 1999. The functional importance of parasites in animal communities: many roles at many levels? Int. J. Parasitol. 29, 903-914.

Poulin, R., 2006. Global warming and temperature-mediated increases in cercarial emergence in trematode parasites. Parasitology 132, 143-151.

Poulin, R., Mouritsen, K.N., 2006. Climate change, parasitism and the structure of intertidal ecosystems. J. Helminthol. 80, 183-191.

Rasmussen, C., 2011. Detailed method description for laser diffraction of soil- and sediment samples. Department of Geoscience, Aarhus University, pp. 2-42.

Reise, K., van Beusekom, J.E.E., 2008. Interactive effects of global and regional change on a coastal ecosystem. Helgol. Mar. Res. 62, 85-91.

Rothschild, M., 1938. Further observations on the effect of trematode parasites on Peringia ulvae (Pennant, 1777). Novit. Zool. 41, 84-102.

Schückel, U., Kröncke, I., 2013. Temporal changes in intertidal macrofauna communities over eight decades: a result of eutrophication and climate change. Estuar. Coast. Shelf Sci. 117, 210-218.

Scott, M.E., 1987. Regulation of mouse colony abundance by Heligmosomoides polygyrus. Parasitology 95, 111-128.

Sousa, W.P., 1991. Can models of soft-sediment community structure be complete without parasites? Am. Zool. 31, 821-830.

Stewart, R.JA, Dossena, M., Bohan, D.A. Jeppesen, E., Kordas, R.L, Ledger, M.E., Meerhoff, M., Moss, B., Mulder, C., Shurin, J.B., Suttle, B., Thompson, R., Trimmer, M., Woodward, G., 2013. Mesocosm experiments as a tool for ecological climate-change research. Adv. Ecol. Res. 48, 71-181.

Studer, A., Poulin, R., 2013. Differential effects of temperature variability on the transmission of a marine parasite. Mar. Biol. 160, 2763-2773.

Studer, A., Thieltges, D.W., Poulin, R., 2010. Parasites and global warming: net effects of temperature on an intertidal host-parasite system. Mar. Ecol. Prog. Ser. 415, 11-22.

Thieltges, D.W., Rick, J., 2006. Effect of temperature on emergence, survival and infectivity of cercariae of the marine trematode Renicola roscovita (Digenea: Renicolidae). Dis. Aquat. Org. 73, 63-68.

Thieltges, D.W., de Montaudouin, X., Fredensborg, B., Jensen, K.T., Koprivnikar, J., Poulin, R., 2008. Production of marine trematode cercariae: a potentially overlooked path of energy flow in benthic systems. Mar. Ecol. Prog. Ser. 372, 147-155.

Thomas, F., Renaud, F., Guegan, J.F., 2005. Parasitism and ecosystems. Oxford University Press, Oxford.

Volkenborn, M., Robertson, D.M., Reise, K., 2009. Sediment destabilizing and stabilizing bio-engineers on tidal flats: cascading effects of experimental exclusion. Helgol. Mar. Res. 63, 27-35.

Ward, J.N., Pond, D.W., Murray, J.W., 2003. Feeding of benthic foraminifera on diatoms and sewage-derived organic matter: an experimental application of lipid biomarker techniques. Mar. Environ. Res. 56, 515-530.

Wood, C.L., Byers, J.E., Cottingham, K.L., Altman, I., Donahue, M.J., Blakeslee, A.M.H., 2007. Parasites alter community structure. Proc. Natl. Acad. Sci. 104, 9335-9339. 